\title{
Age-related differences in the response of the isolated testicular capsule of the rat to norepinephrine, acetylcholine and prostaglandins
}

\author{
Joseph R. Davis and Arthur M. Horowitz \\ Department of Pharmacology and Therapeutics, Loyola University of Chicago \\ Stritch School of Medicine, Maywood, Illinois 60153, U.S.A.
}

\begin{abstract}
Summary. The contractile response of the isolated testicular capsule to acetylcholine, norepinephrine and prostaglandins (A-2, E-1 and F-2 $\alpha$ ) was related to the age of the rat. Norepinephrine and PGA-2 caused an increased capsular response between 45 and 60 days of age, the time at which spermiogenesis begins. It is suggested that the activity of the testicular capsule is involved in the transport of non-motile spermatozoa from the testis and into the epididymis.
\end{abstract}

\section{Introduction}

Previous reports from this laboratory have described the isolation of the testicular capsule of the adult rat and its contractions in response to several pharmacological agents (Davis \& Langford, $1969 \mathrm{a}, \mathrm{b}, 1970,1971)$. In addition, smooth muscle was found to be present in the testicular capsule offering a reasonable anatomical explanation for such drug-induced contractions (Davis, Langford \& Kirby, 1970).

Spermatozoa first attain motility in the epididymis, but the factors responsible for the transport of non-motile spermatozoa from the seminiferous tubules out of the testis and into the epididymis have remained obscure. There have been suggestions that the testis as a whole organ might be capable of undergoing spontaneous movements, as indicated by the report of interstitial pressure changes in the testis of an anaesthetized rabbit (Holstein \& Weiss, 1967). The secretion of intratubular fluid by the Sertoli cell and its association with spermatids in early spermiogenesis (Barack, 1968), as well as seminiferous tubular contractions mediated by testosterone and dihydrotestosterone (Urry, Asay \& Cockett, 1976), may also contribute to the transport of spermatozoa. The isolated capsule of the rabbit (Davis, Langford \& Kirby, 1970) and human (Davis \& Langford, 1970; Firlit, King \& Davis, 1975 ) testis exhibits periodic rhythmic and powerful spontaneous contractions in the absence of any drug. These data indicate that the rhythmic contractions of the testicular capsule could function to massage the seminiferous tubules and thus provide a pumping action which transports the non-motile spermatozoa from the seminiferous tubules out of the testis and into the epididymis where they can become motile.

Little is known of the relationship of prostaglandins to testicular function with respect to age. Prostaglandin synthesis in the rat testis has been reported to be age dependent (Ellis \& Baptista, 1969) and had the same distribution as the enzymes responsible for their synthesis. In addition, prostaglandins have been shown to stimulate, inhibit and maintain rabbit testicular contractions in vitro (Hargrove, Johnson \& Ellis, 1971; Ellis, Johnson \& Hargrove, 1972; Hargrove, Seeley, Johnson \& Ellis, 1973).

The present experiments were designed to investigate whether a relationship exists between the onset of spermiogenesis and the degree of contraction of the rat isolated testicular capsule which can be produced by norepinephrine, acetylcholine and prostaglandins.

\section{Materials and Methods}

Animals. Male Sprague-Dawley rats were purchased from the Holtzman Company, Madison, Wisconsin, and housed, 5/cage, under controlled temperature $\left(22^{\circ} \mathrm{C}\right)$ and illumination $(12 \mathrm{~h}$ light $(07: 00-19: 00 \mathrm{~h}) / 24 \mathrm{~h})$. Food and water were always available. Rats aged 30, 45, 60 and 90 days and 
weighing approximately $100,200,300$ and $380 \mathrm{~g}$, respectively, were decapitated and the testicular capsule was isolated and prepared as described previously (Davis \& Langford, 1969a, b). The testicular capsule was mounted in a $10-\mathrm{ml}$ isolated-organ bath with a ligature attached to the superior pole and leading to a linear motion transducer (Phipps \& Bird, Inc.). Isotonic contractions of the testicular capsule, with a tissue load weight of $100 \mathrm{mg}$ to give a magnification of $\times 100$, were recorded on a Texas Instruments Oscillo-riter recorder with a paper speed of $0.25 \mathrm{~mm} / \mathrm{sec}$. The bathing medium was Tyrode's solution aerated with air and maintained at a constant temperature of $32^{\circ} \mathrm{C}$.

Bioassay procedures. Acetylcholine and norepinephrine were dissolved in Tyrode's solution and distilled water, respectively. Stock solutions of prostaglandin (PG) A-2, PGE-1 and PGF-2 $\alpha$ were made up in $95 \%$ ethanol and dissolved in a $0.2 \mathrm{M}$-sodium phosphate buffer, $\mathrm{pH} \mathrm{6.4.} \mathrm{A} \mathrm{dose} \mathrm{of} 0.1 \mu \mathrm{g}$ acetylcholine $/ \mathrm{ml}\left(5.5 \times 10^{-7} \mathrm{M}\right)$ and $1.0 \mu \mathrm{g}$ norepinephrine $/ \mathrm{ml}\left(3.0 \times 10^{-6} \mathrm{M}\right)$ was added before any dose-response studies to establish homogeneity of the population. Dose-response curves for the added acetylcholine, norepinephrine, PGA-2, PGE-1 and PGF-2 $\alpha$ were obtained by the addition of aliquots of $200 \mu$ l or less of each compound into the organ bath by means of a precision micropipette. The ethanolic phosphate buffer solvent employed for the PGs had no effect on the rat isolated testicular capsule in the amounts used in the present study.

Statistical evaluation. Standard statistical methods were used to apply Student's $t$ test for comparison of mean values (Goldstein, 1964). The data for each age studied represents the average of 5 testicular capsules, each obtained from different rats. Dose-response curves for only one drug were carried out on each testicular capsular preparation to avoid any possible drug interactions. The concentration of drug that produced $50 \%$ of the maximal effect obtainable has been designated the EC50.

\section{Results}

Increasing age of the rats was proportional to the increase in body weight, the weight of the whole testis, the weight of the isolated testicular capsule and the resting length of the testicular capsule in vitro (Table 1). As shown in Text-fig. 1 the age of the rat affected the typical response of the isolated testicular capsule to equimolar concentrations of norepinephrine, acetylcholine and PGs. For rats aged 30 and 90 days, equimolar concentrations of norepinephrine, PGA-2 and PGF-2 $\alpha$ induced a significant difference in the degree of tissue contraction, while acetylcholine and PGE-1 had no significant effect (Table 2). The testicular capsule response in the 90-day-old rats was greater with norepinephrine and PGA-2 and less with PGF-2 $\alpha$. In terms of percentage shortening of the isolated testicular capsule, at 30 days of age, the response of the capsule to acetylcholine was 10.3 times greater than the corresponding response to norepinephrine (Table 3). The response of the testicular capsule to acetylcholine remained essentially constant up to 90 days even though there was a $150 \%$ increase in the resting length of the capsule in the age range studied, indicating that the amount of smooth muscle mass may not play a role in determining the response of the capsule to a particular agent. The response of the testicular capsule to norepinephrine increased markedly after 45 days of age, which corresponded to the onset of puberty in the rat.

Table 1. Effect of age of the rat on body weight, the weight of the intact testis, the weight of the isolated testicular capsule and the resting length of the testicular capsule

\begin{tabular}{|c|c|c|c|c|}
\hline & \multicolumn{4}{|c|}{ Age (days) } \\
\hline & 30 & 45 & 60 & 90 \\
\hline \multirow{6}{*}{$\begin{array}{l}\text { Body weight (g) } \\
\text { Weight of intact testis (g) } \\
\text { Weight of isolated } \\
\text { testicular capsule (mg) } \\
\text { Resting length of testicular } \\
\text { capsule (mm) }\end{array}$} & $104 \cdot 1 \pm 3.93$ & $206 \cdot 2 \pm 3 \cdot 76$ & $288.4 \pm 8.44$ & $385 \cdot 1 \pm 13 \cdot 18$ \\
\hline & $0.42 \pm 0.04$ & $0.99 \pm 0.06$ & $1.47 \pm 0.09$ & $1.77 \pm 0.04$ \\
\hline & & & & \\
\hline & $16.26 \pm 1.47$ & $32.33 \pm 1.08$ & $44 \cdot 12 \pm 2 \cdot 89$ & $60 \cdot 54 \pm 4 \cdot 58$ \\
\hline & & & & \\
\hline & $11 \cdot 10 \pm 0.55$ & $15.25 \pm 0.36$ & $16.55 \pm 0.48$ & $17 \cdot 60 \pm 0.38$ \\
\hline
\end{tabular}




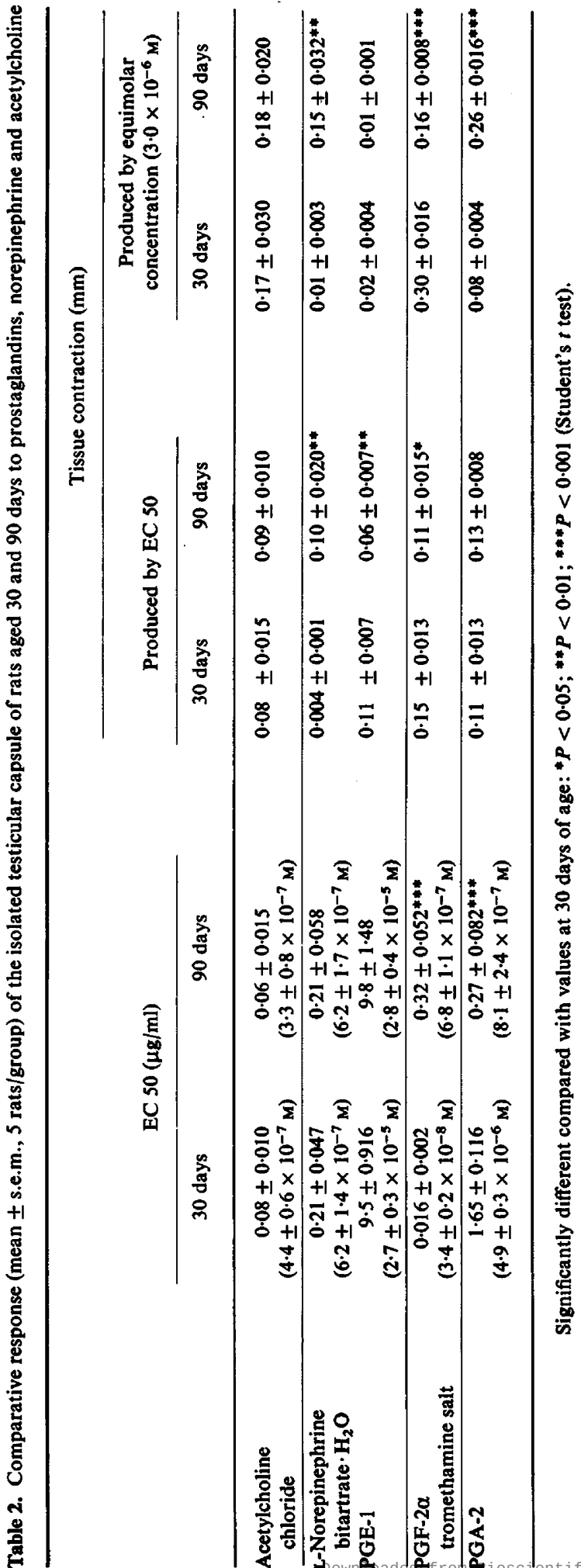


30 Days
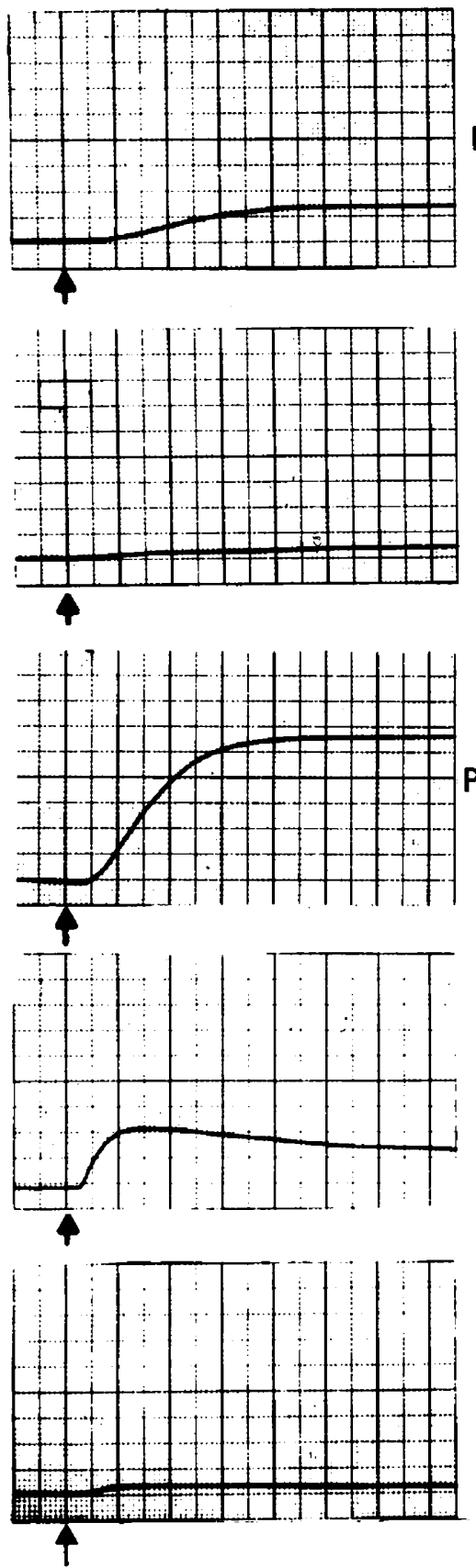

90 Days

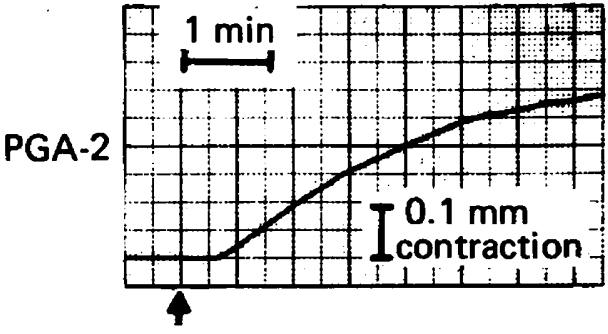

PGE-1
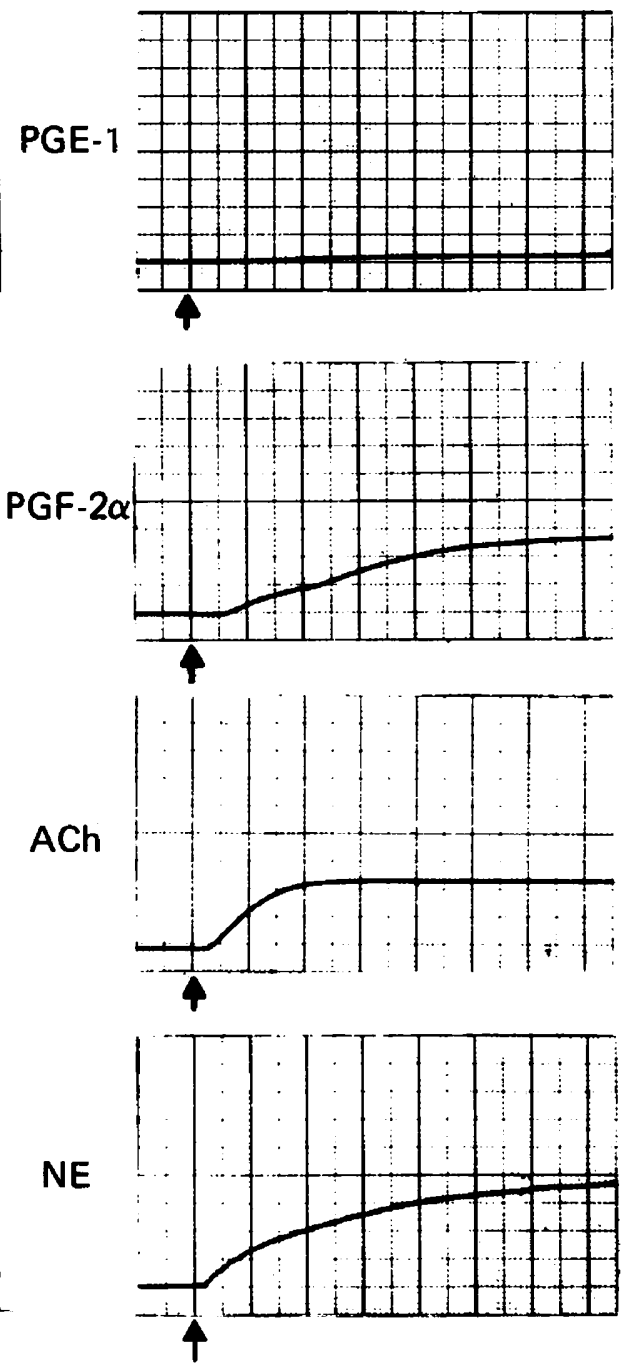

Text-fig. 1. Effect of age on the response of the isolated testicular capsule of rats of different ages to equimolar concentrations $\left(3.0 \times 10^{-6} \mathrm{M}\right)$ of prostaglandins $(\mathrm{PG})$, norepinephrine $(\mathrm{NE})$ and acetylcholine $(\mathrm{ACh})$. Each large square shown on the chart paper represents $5 \mathrm{~mm}$ and the response magnification was $\times 100$. The recordings shown were typical of the total of 5 in each experiment. 
Table 3. The response of the isolated testicular capsule of the rat to acetylcholine $(0 \cdot 1 \mu \mathrm{g} / \mathrm{ml}$, $\left.5.5 \times 10^{-7} \mathrm{M}\right)$ and norepinephrine $\left(1.0 \mu \mathrm{g} / \mathrm{ml}, 3.0 \times 10^{-6} \mathrm{M}\right)$

\begin{tabular}{|c|c|c|c|c|}
\hline & \multicolumn{4}{|c|}{ Age (days) } \\
\hline & 30 & 45 & 60 & 90 \\
\hline $\begin{array}{l}\text { Acetylcholine chloride } \\
\text { L-Norepinephrine bitartrate } \cdot \mathrm{H}_{2} \mathrm{O}\end{array}$ & $0.76 \pm 0.15$ & $0.59 \pm 0.12$ & $0.82 \pm 0.25$ & $\begin{array}{l}0.59 \pm 0.14 \\
0.85 \pm 0.18\end{array}$ \\
\hline
\end{tabular}

Values are mean \pm s.e.m. for 5 experiments and represent the \% shortening ( $\mathrm{mm}$ tissue contraction/resting length of testicular capsule).

\section{Discussion}

The present data demonstrate that the response of the isolated testicular capsule to neurohumoral agents changes with an increase in age of the rat. At 20 days of age, the rat testis is abdominal and clearly prepubertal, consisting of many small developing seminiferous tubules with several layers of spermatogonia and transitional to early pachytene primary spermatocytes. By 30 days, the testis has descended into the scrotum and about half of the tubules contain spermatids of the cap and acrosome phases of spermiogenesis. The onset of spermatid maturation begins at 45-50 days of age and spermatogenesis is complete by 90 days, the testis then being considered to be adult in that mature spermatozoa are produced (Davis \& Firlit, 1966). The sudden increase in the contractile response of the isolated testicular capsule of the rat to norepinephrine and PGA-2 which was observed in the present study appears to coincide with the onset of production of spermatids in the maturation phase of spermiogenesis at 50 days of age.

The contractions of the isolated testicular capsule can be attributed to the smooth muscle cells located within the tunica albuginea. Moreover, both adrenergic and cholinergic nerve terminals have been identified in the adult rat testicular capsule, with the adrenergic supply predominating (Bell \& McLean, 1973). The different responses induced by the drugs tested in the present study may be related to changes in the receptors during maturation, as has been reported for PGE-2 and PGF-2 $\alpha$ effects on smooth muscle preparations from the colon and stomach of mature and immature rats (Okpako, 1976). In addition, the postnatal response of the rabbit testicular capsula to PGF-2 $\alpha$ and PGE-1 has been suggested to be related to the development of adenyl cyclase activity (Mitchell \& Seeley, 1977).

The EC50 values for norepinephrine producing a contraction of the isolated testicular capsule remained constant in 30- and 90-day-old rats (Table 2) and therefore the increase in the capsular contractions in response to the addition of the same dose of norepinephrine $\left(3.0 \times 10^{-6} \mathrm{M}\right)$ with age (Table 3) appears to involve an enhancement in the magnitude of the contractile response rather than a greater affinity for the receptor. In addition, the increased contractile response to norepinephrine in 90-day-old adult rats does not appear to be correlated with the development of the amount of smooth muscle because the response to acetylcholine remained constant in animals 30-90 days of age. However, the EC50 value for PGA-2 producing a contraction of the rat isolated testicular capsule was lower at 90 than at 30 days of age, indicating that the increased contraction of the testicular capsule with age following the addition of the same dose of $1.0 \mu \mathrm{g} \mathrm{PGA}-2 / \mathrm{ml}\left(3 \times 10^{-6} \mathrm{M}\right)$ (Table 2) may involve a greater affinity for the receptor as the animal reaches adulthood. Therefore, in addition to norepinephrine, prostaglandins may also be important modulators of testicular capsular contractions in the rat because the responses to PGA-2 and PGF-2 $\alpha$ differed, PGF-2 $\alpha$ being more effective at 30 days and PGA-2 at 90 days of age.

In the present study, the agonist-induced contraction of the isolated testicular capsule sometimes 'faded' temporarily from a rapidly attained peak; this abrupt relaxation was observed at 30 days of age for every agonist studied and increased with dosage. The 'fade' could have arisen either from the kinetics of the drug-receptor interaction (Paton \& Waud, 1964) or from a change such as reduced 
availability of $\mathrm{Ca}^{++}$, in the stimulus-contraction coupling process (Fastier, Purves \& Taylor, 1973).

The increased contractile response of the isolated testicular capsule of the rat to norepinephrine and PGA-2 which was observed at the onset of puberty may play a role in the transport of non-motile spermatozoa from the testis into the epididymis, where the spermatozoa attain their motility. It is possible that smooth muscle receptor changes taking place at puberty may be responsible for the presently observed increase in the contractile response of the rat testicular capsule to norepinephrine and PGA- 2 and the reduced sensitivity to PGF- $2 \alpha$.

This work was supported by Research Grant HD 09416-02 from the National Institute of Child Health and Human Development, National Institutes of Health, U.S. Public Health Service. A.M.H. is a predoctoral trainee of Loyola University of Chicago. We are grateful to Dr J. E. Pike (Upjohn Co.) for a generous gift of prostaglandins.

\section{References}

BARACX, B.M. (1968) Transport of spermatozoa from seminiferous tubules to epididymis in the mouse: a histological and quantitative study. J. Reprod. Fert. 16, 35-48.

BeLl, C. \& MCLEAN, J.R. (1973) The autonomic innervation of the rat testicular capsule.J. Reprod. Fert. 32, 253-258.

Davis, J.R. \& FirLIT, C.F. (1966) The germinal epithelium of cryptorchid testes experimentally induced in prepubertal and adult rats. Fert. Steril. 17, 187-200.

Davis, J.R. \& LANGFord, G.A. (1969a) Response of the testicular capsule to acetylcholine and noradrenaline. Nature, Lond. 222, 386-387.

DAvis, J.R. \& LANGFoRD, G.A. (1969b) Response of the isolated testicular capsule of the rat to autonomic drugs. J. Reprod. Fert. 19, 595-598.

DAvis, J.R. \& LANGFord, G.A. (1970) Pharmacological studies on the testicular capsule in relation to sperm transport. In The Human Testis, Vol. 10, pp. 495-514. Eds E. Rosemberg \& C. A. Paulsen. Plenum Press, New York.

Davis, J.R. \& Langford, G.A. (1971) Comparative responses of the isolated testicular capsule and parenchyma to autonomic drugs. J. Reprod. Fert. 26, 241-245.

Davis, J.R., Langforo, G.A. \& Kirby, P.J. (1970) The testicular capsule. In The Testis, Vol. 1, pp. 281-338. Eds A. D. Johnson, W. R. Gomes \& N. L. VanDemark. Academic Press, New York.

Ellis, L.C. \& BaptistA, M.H. (1969) A proposed mechanism for the differential sensitivity of the immature rat testis. In Radiation Biology of the Fetal and Juvenile Mammal, pp. 963-974. Eds M. R. Sikov \& D. D. Mahlum. U.S. Atomic Energy Commission, Division of Technical Information, Washington.

Ellis, L.C., Johnson, J.M. \& Hargrove, J.L. (1972) Cellular aspects of prostaglandin synthesis and testicular function. In Prostaglandins in Cellular Biology, pp. 385-398. Eds P. W. Ramwell \& B. B. Pharriss. Plenum Press, New York.
Fastier, F.N., Purves, R.D. \& Taylor, K.M. (1973) Observations on 'fade': a complication of the contractile response of smooth muscle to a large dose of an agonist. Br. J. Pharmac. 49, 490-497.

FirLit, C., King, L.R. \& Davis, J.R. (1975) Comparative responses of the isolated human testicular capsule to autonomic drugs. J. Urol. 113, 500-504.

GoldsteIn, A. (1964) Biostatistics: An Introductory Text. The Macmillan Company, New York.

Hargrove, J.L., Johnson, J.M. \& Ellis, L.C. (1971) Prostaglandin $E_{1}$ induced inhibition of rabbit testicular contractions in vitro. Proc. Soc. exp. Biol. Med. 136, 958-961.

Hargrove, J.L., Seeley, R.R., Johnson, J.M. \& Ellis, L.C. (1973) Prostaglandin like substances: initiation and maintenance of rabbit testicular contraction in vitro. Proc. Soc. exp. Biol. Med. 142, 205-209.

Holstein, A.F. \& Weiss, C. (1967) Uber die Wirkung der Glatten Muskulatur in der Tunica Albuginea in Hoden der Kaninchens: Messeungen des Interstitiellen Druckes. Z. ges. exp. Med. 142, 334-337.

Mitchell, M.A. \& Seeley, R.R. (1977) Autorhythmic contractions of the postnatal rabbit testicular capsule and its response to prostaglandins, epinephrine and acetylcholine. Biol. Reprod. 17, 591-598.

OKPaKo, D.T. (1976) Effects of animal maturity on smooth muscle and blood pressure responses to prostaglandins $\mathrm{E}_{2}$ and $\mathrm{F}_{2} \alpha$. J. Pharm. Pharmac. 28, 613-616.

Paton, W.D.M. \& WaUd, D.R. (1964) A quantitative investigation of the relationship between the rate of access of a drug to receptor and the rate of onset or offset of action. Arch. exp. Path. Pharmak. 248, 124 143.

URrY, R.L., AsAY, R.W. \& CROCKeTt, A.T.K. (1976) Hormonal control of seminiferous tubule contractions: a hypothesis of sperm transport from the testicle. Invest. Urol. 14, 194-197.

Received 17 January 1978 